PART 3

Widening the Scope of Ethical Deliberations 
Hub Zwart - 9789004392137

Downloaded from Brill.com04/26/2023 11:15: ๑๑AM via free access 


\title{
In the Beginning Was the Genome: Genomics and the Bi-Textuality of Human Existence
}

\author{
Hub Zwart ${ }^{1}$
}

\section{Introduction $^{2}$}

The Human Genome Project (HGP) has been hailed as an important milestone, not only for the history of the life sciences, but even for humanity as such (Collins 2006). It was presented as an endeavour that would transform the practice of medicine but also change the course of human history (Davies 2001, cf. Zwart 2015). And yet, although the HGP undoubtedly altered the way in which biomedical research is conducted (Collins 1999), the actual benefits for human society (notably in terms of novel treatments for diseases, for instance) have been limited so far (Collins 2011), so that the great expectations initially associated with classical genomics have now been displaced to newer hype-prone areas of research, such as next generation sequencing (NGS), personalised genomics, precision medicine and gene editing. In this contribution I will argue, however, that the cultural and spiritual relevance of the HGP, has been quite substantial. Genomics, I will contend, has affected our self-understanding as 'rational animals' and as stewards of creation (Zwart 2009). More specifically, the HGP revivified the (allegedly outdated) question of the soul (Ahmed and Suleman 2017), a key issue not only in Christian, but also in Islamic thinking; two intellectual traditions of global significance for which Aristotle has been a major source of inspiration, in combination with the Bible and the Quran respectively. The aim of this contribution is to assess the broader, cultural rel-

1 Professor of Philosophy at the Faculty of Science and Director of the Institute for Science in Society, Radboud University Nijmegen, the Netherlands, h.zwart@science.ru.nl

2 I profited significantly from the comments and discussions which evolved during the seminar "Islamic Ethics and the Genome Question". A previous version of this paper was published in The New Bioethics: A Multidisciplinary Journal of Biotechnology and the Body, 24 (1), pp. 26-43. DOI: 10.1080/20502877.2018.1438776

(C) HUB ZWART, 2019 | DOI:10.1163/9789004392137_009

This is an open access chapter distributed under the terms of the prevailing CC-BY-NC License at the time of publication. 
evance of human genomics and its philosophical, spiritual and ethical ramifications by staging a mutual learning dialogue (or triangulation) between genomics research, continental philosophy and religious (notably Christian and Islamic) anthropology.

First of all I will consider the way in which the cultural and spiritual relevance of the HGP was addressed by Francis Collins, at the time Director of the International Human Genome Sequencing Consortium during the famous Press Conference in June 2000 when the human genome sequence was proudly presented to a global audience, but even more elaborately in his autobiographical retrospect (Collins 2006). Subsequently, opting for a continental philosophical perspective (notably building on the work of key authors such as Hegel, Teilhard de Chardin and Lacan), I will address the question whether and to what extent the human genome can be regarded as the "language of God" (Collins 2006), or as a molecular update of the Aristotelian concept of the soul. Starting from the claim made by Max Delbrück that Aristotle must be credited with having predicted DNA, I will reread De Anima to explore whether insights coming from genomics indeed concur with Aristotle's understanding of the relationship between soul and life. My conclusion will be that human existence results from a dialectical interplay between two types of text: on the one hand the molecular language of DNA, on the other hand the languages of our socio-cultural environments. As living beings we are susceptible to the language of the genome, but as cultural and spiritual beings humans are also susceptible and answerable to the "language of the Other", providing a symbolic scaffold for moral responsibility and ethics.

\section{The Adoration of a Genome}

Eighteen years ago, on June 26, 200o, President Bill Clinton, together with scientists Francis Collins and Craig Venter, solemnly announced, from the East Room of the White House (urbi et orbi, so to speak), that the Human Genome Project (HGP) was rapidly nearing its completion. This carefully orchestrated, widely broadcasted press conference resembled a religious ceremony in various ways. As if Clinton, Collins and Venter conducted a spiritual service before an international gathering of top scientists, journalists and politicians, congregated in solemn adoration. The near-religious atmosphere was underscored by the fact that the addresses delivered on that occasion were punctuated by "blatantly religious references", as Collins himself phrased it (2006, 2), such as the statement by Clinton: "Today we are learning the language in which God created life"; or the statement by Collins: "Today we celebrate the revelation of 
the first draft of the human book of life" (National Human Genome Research Institute, 2000).

In his autobiographical retrospect, published six years after the event, Francis Collins confessed that for him, as a Christian scientist, the sequencing of the human genome was indeed "an occasion of worship" (2006, 3). He confessed to be "in awe of this molecule" (102), this "wondrous" map, this "miraculous" code, "previously known only to God". The process of "uncovering this most remarkable of all texts" held a special significance, since the human genome was "written in the DNA language by which God spoke life into being" (123). Therefore, the human sequence invoked in him "an overwhelming sense of awe" (123).

Interestingly, however, besides an electronic screen claiming that the decoding of the book of life represented a milestone for humanity, there was nothing to be seen during the press conference, nothing visibly on display. The mysterious centrepiece of the whole event, the focal point of attention, was emphatically absent, like a spectral Lacanian "thing". The dramaturgic miseen-scène revolved around a void. Not only because the sequencing process was still ongoing (the celebration, for various complicated strategic reasons, was organised somewhat prematurely), but first and foremost because a strand of nucleotide code can only be made visible through highly technical means. It is a molecularised, computerised version of what we are, rather than a portrait or mirror lay audiences can relate to. At best, the typical output of automated sequencing machines resembles modernistic (decidedly non-figurative) art. Similar to Holy Mass, one could argue, the presence of the object of worship (the human genome) had to be presupposed or envisioned by a congregation of committed believers. But this concurred with Collins' conviction that the human code is the molecular equivalent of sacred Scripture, something that would be trivialised and desecrated by direct exposure to a public gaze.

The June 2000 event has been compared with the Adoration of the Mystic Lamb (Zwart 2010), a famous medieval polyptych altarpiece on display in Ghent's Saint Bavo Cathedral, created almost six centuries ago (between 1430 and 1432) by the Limburgian artists Hubert and Jan van Eyck: a highlight of late medieval religious art. Its central panel assembles knights, martyrs, hermits, pilgrims, saints, priests, burghers and nobility in a joint celebration, comparable to how the White House press conference brought together scientists, journalists, policymakers and heads of state in a similar gathering, as representatives (the front row as it were) of humankind, beholding a sublime, ethereal object. The Van Eyck altarpiece stages a culmination point, a final station in a collective pilgrimage. Like the lamb on the central panel, the human sequence is expected to deliver humanity from all kinds of evil: erasing cancer 
and producing cures for degenerative congenital diseases such as Alzheimer's: the HGP as a "soteriological" project (Song 2003). Indeed, it was claimed that, due to this "most wondrous map... Our children's children will know the term cancer only as a constellation of stars" (National Human Genome Research Institute, 2000).

But whereas human beings, trees, flowers and buildings are represented by the Van Eyck brothers with dexterous craftsmanship and exacting realism, the central figure (the mystic lamb) is an iconic, formulaic image, a screen or semblance covering up an empty spot, an unconceivable, un-representable "something", and the same applies to the dove hovering above (representing the Holy Spirit, the third component of the Holy Trinity). In Catholic liturgy, the Lamb (Jesus) is not literally visible, but present via a mystic event known as transubstantiation. The lamb image is inserted at the focal point of convergence to conceal a void, for the divine object is only spiritually perceivable (for true believers). Also in this respect, the late medieval artwork and the HGP press conference resemble one another. The focus of attention is a spectral, absent, imaginary entity, an adulated iconic screen covering a void, indicating the advent of something which is keenly anticipated, but not yet tangibly there.

\section{Genomics and Self-knowledge}

The spiritual aura radiating from the HGP (as one the highlights of contemporary technoscience) seems at odds with the decidedly "secular" profile of modern scientific research. Is this a coincidence, an oddity resulting from the fact that one of the key players in the room (Collins) happened to be a Christian? Or should we rather see it as a symptomatic feature which points to a more fundamental dimension of contemporary science: an unconscious aspiration, obfuscated and disavowed perhaps in normal every-day research, but resurging on such prominent occasions? At the Press Conference, the HGP was framed as a crucial station on a long journey of exploration, which began with the famous motto inscribed on the temple of Apollo's at Delphi more than twenty-five centuries ago: "Know thyself" ( $\left.\gamma v \omega \theta_{l} \sigma \varepsilon \alpha v \tau o ́ v\right)$. Self-knowledge remains the ultimate goal of our cupido sciendi, our "will to know", and the HGP entailed the promise that we will now finally be able to know ourselves (Zwart 2007). Venter for instance, both at the press conference and in his autobiography (Venter 2007), describes the human genome as "our own instruction book" and as "the draft of the human book of life". The human genome was regarded by many as our "blueprint", and as the HGP came off ground, the twenty-five 
century old quest for human self-knowledge seemed to be entering a decisive phase.

But also in terms of self-knowledge, the HGP resulted in a disappointment, for in the course of the project something remarkable happened. Initially, estimates of the number of genes on the human genome tended to vary greatly. Walter Gilbert (1992) had suggested that the human genome contained something like 100.000 genes a figure widely quoted and adopted (IHGSC 2001, 898), but James Watson (2002) even mentioned 248.0oo genes as a probable estimate. In 2000, an estimate of 120.000 genes was still proposed (Liang et al, 2000). In 2001, however, the International Human Genome Sequencing Consortium (IHGSC) reduced the official estimate to $\sim 31.000$ genes. And in 2004, in the landmark paper that presented the finished version, covering $99 \%$ of the human genome, a more or less final estimate was given of $\sim 22.500$ genes (IHGSC 2004, cf. van Ommen 2005, 931). This was something of a disappointment indeed, or even a narcissistic offence (Freud 1917/1947; cf. Zwart 2007)), not only in comparison to previous estimates, but also in comparison to the number of genes on the genomes of other model organisms such as Drosophila melanogaster ( 14.000 genes), Caenorhabditis elegans ( 19.000 genes) and Arabidopsis thaliana ( 25.00o genes). Indeed, it raised the question "what does set us apart from flies and worms" (Van Ommen 2005).

Dialectically speaking, the realisation of the HGP entailed an important experience, namely that the human existence proves decidedly more complex than was initially expected. The HGP undermined (or "negated" in dialectical terms) rather than confirmed a genetic reductionist understanding of the genome as our "blueprint". In order to know ourselves, a more comprehensive portrayal is required, which not only encompasses molecular genomics, but also envisions how we come to terms with our socio-cultural environment. We are not only the product of our genes, but abut forged by culture as well. Human existence results from a dialectical interplay between two types of texts: by the "language" of the genome, but also by the "symbolic order" (Lacan): i.e. the multiple (political, scientific, religious and moral) forms of discursivity that constitute human civilisation or Sittlichkeit (Hegel 1970).

The surprisingly small number of genes raised the philosophical question how humans are able to create a highly complex, artificial environment, a technological world or "technotope", equipped with a genome that contains such a small number of genes? While we are exploring and unraveling the structure of the universe and reshaping our environment at an unprecedented scale and pace, the genetic basis for our unique talents and creativity remains unclear. On the level of our genome, we do not seem that different at all. Our uniqueness and otherness is hardly reflected by our genes. One conclusion may be 
that, apparently, we are not that unique and different as a species after all. As Venter phrased it during his White House speech: "We [...] have many genes in common with every species on Earth [...] we're not so different from one another" (National Human Genome Research Institute, 2000).

But this is not the only conclusion we might draw. Another possibility is that we should look for the source of our uniqueness and complexity as human beings elsewhere. As the Gospel of Saint John phrases it: in the beginning was the word ( $\lambda$ ó 05$)$, but DNA is not the only text which shapes human existence. Our intelligence and creativity also depends on our techno-cultural environment, on our susceptibility and exposure to culture, to words, to discursivity: to the symbolic order, the discourse of the Other, as Jacques Lacan phrased it (1966, $524)$.

Thus, human existence evolves at the intersection of two types of texts. On the one hand the molecular textuality disclosed by genomics and post-genomics research, commencing from the genome (a portmanteau of gene and chromosome), but closely interacting with the metabolome, the transcriptome and various other -omics layers (up to the exposome and the environome: Cheng \& Cooper 2001; Miller \& Jones 2014) that are studied by genomics, metabolomics, transcriptomics and many other -omics fields. The understanding of the genome as a text or code was initiated by Erwin Schrödinger in his classic What is life (1944/1967), but reinforced by the discovery of DNA by Watson and Crick (two researchers who were explicitly inspired by Schrödinger's book: Zwart 2013) and its alphabet of nucleotide letters (A, C, G and T). More recently, the understanding of life in terms of textuality was reconfirmed by the introduction of the CRISPR/Casg technique, allowing gene editing "by the letter", "letter by letter", as Doudna and Sternberg (2017, p. 93) phrase it, enabling the correction of "single-letter mistakes" (p. 10o) in DNA with "single-letter accuracy" (p. 212). The genome is the primordial layer from where multiple circuits and complicated networks of molecular messages pervade living organisms.

But this bio-molecular textuality is complemented by a second type of textuality: the discursivity of the socio-cultural ambiance, again a multi-layered and stratified phenomenon. And also with regard to the textuality of our socio-cultural environment, a primordial layer can perhaps be discerned, consisting of primordial or initiating texts, the equivalent of the genome in the field of the humanities, and likewise referred to as the language of God, namely key textual sources that served as grounding documents for whole cultures, for national languages, ranging from the Bhagavad Gita via the Hebrew Bible up to the New Testament and the Quran. Such documents reflect seminal efforts 
by human authors to respond to an experience calling: the experience of being addressed by a voice from elsewhere, by a speaking Other. ${ }^{3}$

Human genomics and post-genomics evolve in a world populated by 5.8 billion people ( 84 percent of the world population) who report themselves as religiously affiliated. If anything, this astonishing figure reflects a tenacious human predisposition or receptiveness for spirituality. ${ }^{4}$ It has been argued, by Hamer (2005) and others, that this worldwide susceptibility of responsiveness of human beings to the spiritual dimension of existence, resulting in multiple forms of religiosity, is based on the presence of a so-called god gene (VMAT2), hardwiring an inclination towards spirituality into human DNA. But regardless of whether a genetic susceptibility for religious experiences does exist, a number of decisive examples have been recorded where exposure to a Divine $\lambda$ ó $\gamma \circ$ gave rise to experiences of awakening and conversion (or delusion, if you like), inaugurated by susceptible voices such as Jeremiah (626 B.C.), Jesus (3o A.D.) and Mohammed (61o A.D.). Such events (and the various documents resulting from them) seem to point to a basic human susceptibility to be addressed: by textuality in general, but especially by texts of a specific spiritual nature, urging us to question who we are and where we come from: the very questions that spurred scientists like Collins (2006) into sequencing the human genome in the first place. In other words, not the genome as such, but rather the quest for the genome, the desire to know and read the human sequence may tell us something about who we are.

But how should the interaction between these two forms of textuality (between bio-molecular codes and socio-cultural discursivity) be envisioned? As Pierre Teilhard de Chardin (1955) once phrased it, scientific portrayals of humankind (genetic, anatomical, physiological, neurological, genetic, etc.) consistently seem to fall short. They seem to lack a key dimension, namely self-consciousness or world-openness. Humans are animals, but they also represent a leap, a discontinuity, a metamorphosis, a crisis, an awakening. And it is precisely here that the basic human responsiveness to $\lambda$ oros, to words, to the word even (the calling by the Other), seems to play a decisive role. Due to this exposure to $\lambda$ óyos, for those susceptible to it, existence becomes part of a cultural journey, adding an additional existential layer over and above the biological and socio-economic dimensions of human existence. Moreover, Teilhard believed that, at some point in the imminent future, the current collision between science and religion will be sublated into convergence (an event which

3 "Koranic revelation is considered to be a reception of the hyperoriginary text of the Other [which] had already been written" (Benslama 2009, 13)

4 http://www.pewforum.org/2012/12/18/global-religious-landscape-exec/ 
he referred to as the Omega point). From a Teilhardian point of view, the HGP, focussed on the biological textuality of existence, was certainly a decisive milestone on the pathway leading up to this convergence. And yet, at present, we rather seem faced with an ever widening split or gap between techno-scientific and spiritual understandings of human existence.

But maybe genomics can help us to articulate this experience of collision or convergence at with a higher level of resolution as it were. The phrase "In the beginning was the genome" resonates with the conviction that the starting point of life is DNA: the giant molecule which orchestrates the functioning and development of life on the cellular level. The nucleus of every cell, of every fertilised ovum, contains a molecular text composed of sequences of four letters (A, C, G and T). For religious scientists such as Collins, it was via these letters that God breathed life into the mayhem of abiotic matter: the genome as our plan or programme. But the experience of the HGP confirmed that, in order to really come to terms with human existence, we must continue to pay attention to other texts as well, to other instances of $\lambda$ óros; the texts of culture. In other words, we are products of processes of co-creation, of a dialogue involving various types of text: on the one hand the language of the genome, on the other hand the languages of civilisation. It is from this perspective that I will reread Aristotle's De Anima.

\section{Rehabilitating Aristotle}

In modern scientific circles, Aristotle (the proverbial giant on whose discursive shoulders both Christian and Islamic medieval thinkers stood) no longer enjoys a good reputation. ${ }^{5}$ Notably his views on physics tend to be regarded as blatantly misguided. It has been claimed that the modern scientific revolution was only possible because researchers during the early modern period dared to step beyond the Aristotelian worldview. As Rovelli puts it, Aristotle's science is either not considered as science at all or as a failure. ${ }^{6}$ Psychoanalytically speaking, the emergence of modern scientificity required an act of intellectual patricide (Rovelli 2013).

But in the era of DNA and genomics, this verdict is under reconsideration (Mauron 2011). Max Delbrück, one of the founding fathers of molecular biology,

5 For a more extended analysis of the importance of Aristotle for Islamic and Christina understandings of the body and the tension with the modern scientific view see Zwart \& Hoffer (1998)

6 https://www.academia.edu/5739248/Aristotles_physics 
already argued that, in retrospect, Aristotle should be credited for discovering "the principle implied in DNA" (1973, p. 55) and that molecular biology echoes Aristotelian conceptions, as is suggested by the title of his paper (Aristotle-tot(e-totle). Aristotle, Delbrück argues, discovered DNA because he discerned that living beings are composite creatures, composed of form and matter. Or rather: they are matter shaped by (and brought to life by) form. According to Aristotle, the soul is the form and principle of life. But whereas Delbrück predominantly refers to Aristotle's biological writings, the ancient Greek philosopher-biologist from Stagira developed his 'hylemorphic' understanding of life even more

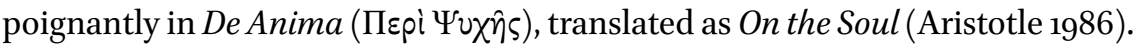
Therefore, I will briefly recapitulate this text, one of the key documents of oriental and occidental metaphysics, intensely studied by both Islamic and Christian scholars, such as Ibn Sinā and Ibn Rushd (known in the West as Avicenna and Averroes) and Thomas Aquinas (1922, Prima Pars Q76).

According to Aristotle, the soul ( $\psi v \times \dot{\eta})$ is the principle ( $\dot{\alpha} p \times \dot{\eta})$ of life (Aristo-

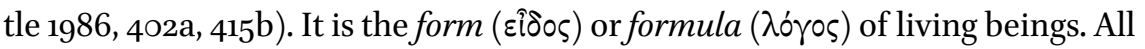
organisms are composite entities: fusions of form ( $\left.\psi v \times \eta^{\prime}\right)$ and matter ( $(2 \lambda \eta)$, re-

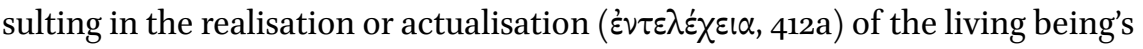
formula or plan ( $\lambda$ óros, $412 \mathrm{~b}, 415 \mathrm{~b}) .^{7}$ The body is regarded as the instrument (oppravov) of the soul (415b). While plants grow and reproduce (as realisations of their "vegetable" soul), animals also perceive and move (as realisations of the sensitive part of their soul). But it is only in humans that Aristotle discerns the presence of a thinking soul (voûs). A scholarly paper, for instance, is a realisation of the thinking soul, a uniquely human dimension, realising itself in

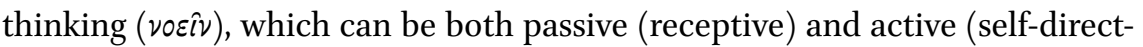
ed).

At this point, however, a basic ambivalence seems at work in Aristotle's text. On the one hand, he regards thinking as a continuation of visual perception in the sense that, whereas via eyesight we perceive the things themselves (as compounds of matter and form), the human mind assesses their form ( $(\hat{i} \delta \circ \varsigma)$ stripped of matter, so that thinking is a more abstract version of sense perception. In other words, whereas perception focusses on external things $(\pi \rho \dot{\alpha} \gamma \mu \alpha \tau \alpha)$, the soul reflects on their inner images $(\varphi \alpha \nu \tau \dot{\alpha} \sigma \mu \alpha \tau \alpha)$. But Aristotle also suggests that the thinking soul focusses, not on the visual shape or form, but rather on the formula ( $\lambda$ óros): the plan of things. Seen from this perspective, Aristotle argues, thinking is more similar to considering letters

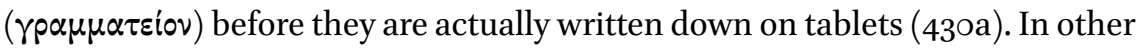

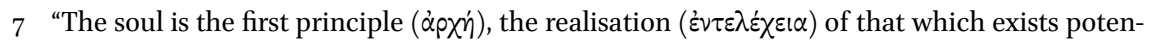
tially: its essential formula ( $\lambda$ ó $о \varsigma) "(415 \mathrm{~b}: 14-15)$. 
words, thinking (in the sense of: mentally considering formula) is comparable to writing a text that has not yet been written: a writing that is not yet realised as actual writing (on a tablet).

The tension between these two versions of thinking, namely thinking as working with mental images $(\varphi \alpha v \tau \dot{\sigma} \sigma \mu \alpha \tau \alpha)$ versus thinking as working with mental characters $(\gamma p \alpha \mu \alpha \alpha \tau \alpha)$, corresponds with a similar ambiguity already described above concerning the concept of form, which may either be inter-

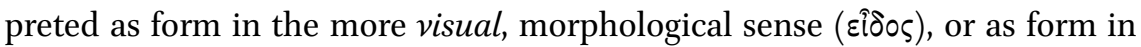
the sense of formula ( $\lambda$ ó Yos): the plan that is realised in the actual living entity. This tension or difference is not clearly spelled out by Aristotle, but it is important to emphasise this in view of later developments, because in contemporary philosophy the distinction between the imaginary (focussed on images or $\varphi \alpha \nu \tau \dot{\sigma} \sigma \mu \alpha \tau \alpha$ ) and the symbolic (focussed on symbols or $\gamma p \alpha \dot{\mu} \mu \mu \tau \tau \alpha$ ) has become quite decisive, while the textuality of life discussed above clearly builds on the latter rather than on the former. Aristotle notices the difference, for instance when he explains that, when we see a beacon, we initially recognise it as fire, until it begins to move, for then we realise that it actually is a signal which signifies something (for instance: the approach of the enemy). This distinction between fire as a (natural) shape (or image) and fire as a (conventional) signal (or symbol, i.e. an element in an alphabet of signals) is not further pursued by Aristotle, but it became increasingly important, not only in contemporary debate, but also in Western culture as such. For whereas ancient Greek culture was still predominantly a visual culture (even in the textual domain oriented on visual, imaginative genres such as epic poetry), one could argue that Christian and Islamic scholars (notably during the medieval era) represented a much more scriptural or textual approach, so that the focus shifted from think-

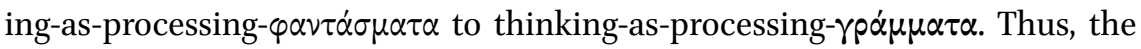
basic tension between images and words, between imaginative and discursive thinking continues to run as a basic epistemological thread through the history of culture as such, ${ }^{8}$ and has been reinforced by decidedly scriptural (textual) cultures, such as Christianity and Islam.

8 Carl Gustav Jung (1911 / 2001) introduced a distinction between two modes of thinking: namely imaginative and discursive thinking. Whereas the latter evolves on the basis of logic and the causality principle, the former relies on association. Historically speaking, Jung argues, discursive thinking is a fairly recent phenomenon. It was introduced by critical minds such as Socrates (the founding father of logic as a philosophical discipline) and further elaborated by Aristotle and scholasticism. Without this intellectual trend (the gradual conversion of the Western mind to discursive thinking), the emergence of modern science would have been unthinkable, Jung argues. 
A final important distinction in De Anima is the one between passive (receptive) and active (self-directed) thinking, notably because Aristotle at a certain point suggests that, whereas the passive soul is perishable like the body (being connected to it as its form), the supra-individual and truly actively thinking soul is independent from perishable living and thinking individuals) and therefore imperishable and everlasting (430a). This seems to suggest that, although no living being can sustain itself without a soul, the thinking soul as such may operate in the absence of a body. To what extent does Aristotle's conception of the soul allow us to deepen our understanding of the human genome in the context of the textuality of human existence?

To begin with, I endorse Delbrück's view Aristotle's hylemorphic conception of life can be regarded as a remarkably lucid anticipation of the principles of genomics. From an Aristotelean perspective, the genome can be considered as the formula, the program or plan ( $\lambda$ ó 05 ) which guides the development of living beings from their embryonic state up to their full realisation ( $\left.\dot{\varepsilon} \nu \tau \varepsilon \lambda \varepsilon^{\prime} \chi \varepsilon 1 \alpha\right)$ as flourishing, self-sustaining and reproducing adults who have fully actual-

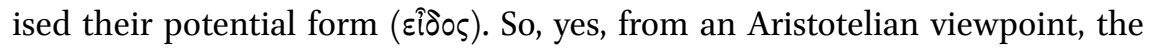
genome can meaningfully be regarded as the text of life, producing living beings from the chemical mayhem of their abiotic surroundings (i.e. inorganic matter). And prominent genomics researchers such as Craig Venter (2013) even argue that, whereas no living organism can exist without its DNA, DNA can be isolated from living beings as pure information, the pure formula of life, everlasting and immortal, processed in computer systems, or even used to reassemble replicas of living organism elsewhere for instance: on other planets, so that microbes in principle can be beamed to Mars, in order to produce an aerobic atmosphere and terraform the planet.

The view that DNA (as carrier of the genome) is the text of life notably applies to the vegetative and sensitive dimensions of bodily existence, however: to metabolism, first and foremost, albeit in continuous interaction with the ecosystem (life as a continuous dialectical dialogue between nature and nurture). But when it comes to understanding the noetic dimension of the soul (the thinking soul or vov̂s), the explanatory power of the genome becomes less obvious. As indicated, a genetic basis for our creativity and intelligence cannot be detected in our genome as such. Although in has been claimed that the human genome contains certain genes that may explain textual-cultural behaviour, dubbed the language gene ( $\left.\mathrm{FOXP}_{2}\right)$ and the god gene (VMAT2) for instance, the presence of such genes can only account for a basic susceptibility or responsiveness to textuality. Our noetic or discursive existence as such cannot be explained on the basis of genomics ('nature', natural textuality) alone, but must be prompted or activated (realised) by exposure to other kinds of text 
as well. Our basic ability to be addressed requires something else besides the genome and the FOXP2 protein (depicted on the left), encoded by FOXP2 gene. It presupposes the existence of a world of language, a socio-cultural ambiance, enabling and facilitating language use, providing a scaffold for the development of intelligent and responsive textual behaviour. This world of language provides a textual infrastructure, a discursive scaffold allowing cultural and moral existence to unfold, in response to the language of the Other, which is already there as a cultural ecosystem. And whereas the ability to be addressed corresponds with Aristotle's concept of passive thinking, our active responsive contribution to and participation in this socio-cultural world of language concurs with what Aristotle refers to as active thinking (discursivity as such), realising or actualising itself via us, but as a symbolic order which is already operating and will continue to function when we as individuals leave the scene (Lacan 1974/2005).

Thus, rereading Aristotle's De Anima likewise prompts us to recognise the basic bi-textuality of human existence. Human self-consciousness emerges at the interface between two types of texts, namely the natural textuality of the body (as studied by molecular biology and genomics) and various social-cultural forms of textuality (analysed by the humanities, from linguistics up to religious studies). In order to understand human existence, physiology must be complemented by philology. Ideally, a state of harmony or at least compatibility and mutual adaptation between both dimensions can be achieved (Lacan 1959-196o/1986, p. 107; Lacan 1956-1957/1994, p. 25), but from the history of culture it is clear that the tension between these two types of text is not that easily to solve, and rather gives rise to chronic experiences of frustration, malaise and failure. But perhaps a reframing in terms of bi-textuality can help us to elucidate the basic split or incongruence that runs through the human condition and was articulated by Sigmund Freud (1930/1948) as discontent in culture. The question is: how to combine or reconcile our openness to the languages of culture (our cultural or even spiritual ecosystems) with the bio-molecular languages of the genome (our biological program)?

\section{Civilisation and its Discontents Reframed}

The phrase "In the beginning was the genome" conveys the idea of DNA as the commencement of life: the biopolymer which generates and orchestrates molecular messages. The nucleus of every cell contains a molecular text composed of sequences of four letters (A, C, G and T) and via them life is breathed into the mayhem of entropic abiotic matter: the genome as our programme. 
But the experience of the HGP confirmed that, in order to come to terms with human existence, we must pay attention to other texts, other instances of

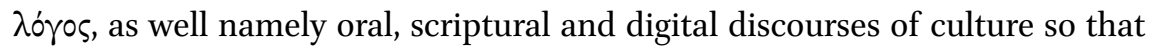
we are products of processes of co-creation, and interaction between various different types of text: on the one hand the languages of molecular biology, on the other hand those of civilisation.

Human beings are driven by two types of texts. They are continuously fuelled by myriads of biochemical messages produced by molecular circuits informed by DNA, but also relentlessly besieged by voices coming from society and culture. And this entails an existential challenge. Various filters and defence systems have evolved to allow us to cope with this unsettling over-abundance, and most of the interactive processing occurs unconsciously, allowing us to focus our attention on tiny samples of (internal or external) signals (Freud 1920, /1940, 27). Various forms of tension, contradiction and confusion may nonetheless result from our susceptibility to these incommensurable types of text. In the course of human history, a split or gap has evolved between our (slowly evolving) Palaeolithic genome and the contrasting demands of our global civilisation (evolving at a tremendous and accelerating pace), a gap which seems too fundamental for genome editing technologies to bridge (Stammers 2017). The pastoral paradise (in which genome and culture once were compatable) seems irretrievably lost (if it ever existed), so that we are facing a chronic incompatibility between the molecular information circuits of embodied nature and the textual cacophony emerging from our socio-cultural ambiance, giving rise to discontent in civilisation, as a persistent and collective human symptom (Freud 1930/1948). Whatever the circumstances, humans always seem to be looking for something more and something else than that which is provided by the immediate material environment.

In this dynamical relationship, a dialectical triad can be discerned. Initially, some level of coherence between genome and cultural Umwelt may have existed (first moment: M1), but at a certain point this pre-established harmony was disrupted: the birth trauma of human culture (M2). According to Jacques Lacan (1966, 1974/2005), language played a crucial role in this, introducing a new and perhaps uniquely human dimension: the desire for things we may conceive or imagine rather than see, smell or grasp. Over the past millennia, this has given rise to a neo-environment: a techno-sphere or socio-sphere, over and above the atmosphere, geosphere and biosphere. But this has failed to appease the tension or gap between what we seek (desire) and what we find (the entities, either natural or artificial, that actually surround us). And this explains the turbulence of human existence in a polarised force-field between two incommensurable types of text: the molecular code of the genome and 
the textual codes of culture. But perhaps, by increasing our literacy on both sides of the equation, (that is, by simultaneously strengthening our fluency in molecular life science research as well as our erudition in the cultural realm) these two textual poles of human existence may eventually become reconciled again $\left(\mathrm{M}_{3}\right)$ ?

As indicated, most of the interaction between these two types of texts takes place unconsciously. As embodied biological beings we are under the sway of the biological unconscious, orchestrated by the genome: a dimension we share with plants, animals and microbes taking care of the metabolism that continuously takes place, within cells as well as within the body as a whole, in close interaction with the environment. The extimate microbiome (both intimate and external) plays an important part in this, as an organ composed of bacteria functioning as a "collective unconscious" (Dinan et al 2015). But over and above the biological unconscious, which we share with other living beings, humans are also prompted by a textual unconscious, which is psychic unconscious, is not a fluid reservoir of bodily or animalistic drives (which would make it biological again), but rather textual and highly organised $(1975,79)$. The psychic unconscious is structured like a language, as Lacan (1981 and elsewhere) phrases it. It is not the seat of primordial instincts, but rather consists of chains of signifiers $(1966,501 \mathrm{ff}$.). This unconscious is a discourse-producing machine speaking to us, albeit in an oblique or indirect manner. For whereas others (children, spouses, colleagues, civil servants, etc.) address us more or less directly, via words and gestures, there is another 'Other', addressing us through dreams, neurotic symptoms and mistakes (slips of the pen), or via in-

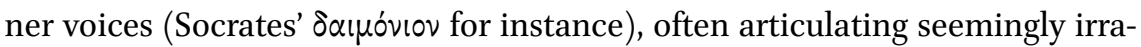
tional desires or incomprehensible concerns (the voice of conscience which, in the case of neurotic patients, may become a paralysing, over-compelling and over-demanding super-ego). In the case of psychotic patients, the unconscious may really surface as a strange, enigmatic language: as an audible, uncanny voice. But non-pathological individuals may likewise be overwhelmed by the language of the Other: by sudden artistic inspirations (the muses), or by

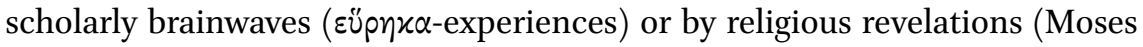
on Mount Sinai, Jesus in Gethsemane, Mohammed in the Hira cave).

For Jacques Lacan, the unconscious is a text-processing, "typographical" realm $(1998,147)$, but different from biological (genomic) textuality (Zwart 2013). Whereas molecular messages coming from the convey informational signals, cultural languages (conveying truth and meaning) seem a uniquely human phenomenon. Whereas the needs, growth patterns and functions of the body are to a certain extern governed by biological messages and codes, human desire is under the sway of the language of civilisation. For Lacan, we 
are "speaking animals", liberated from nature to some extent, but burdened by language, or even sick with language (1974/2005, 90, 93; cf. 1961-1962, 42). And whereas in animals the genome and the environment seem fairly adapted to one another (as in expressed by notions such as fitness), in humans we basically see a failure to adapt, because of our exposure to conflicting messages coming from elsewhere, expelling us from biological forms of existence in which we were once embedded (the biosphere) and opening up a cultural and spiritual realm of truth and meaning, - the symbolic order or noosphere, to use the term coined by Teilhard (1955).

Lacan's analysis of the story of the Sacrifice of Isaac (Genesis 22: 1-13) may serve as an example here (1974/2005). Abraham is not spurred on to climb the mountain in order to sacrifice his son by animalistic or metabolic drives (say, hunger). Rather he responds to a sense of calling: a Divine command, the word of "the Other", not someone who is physically or tangibly present (a spouse, a neighbour, etc.), but a voice coming from "elsewhere". The various physiological phenomena (arousal, metabolism, etc.) that allow him to comply with this command are biological (and genome-based) no doubt, but the crucial invocation that spurs him into action is a phenomenon beyond biology. When he is about to sacrifice his child, however, a voice (a messenger) once again intervenes, so that Abraham once again responds, this time by revoking his original intention. Whereas predators will go for their prey without further ado, humans may deliberate about their sacrifices, and reconsider their choices, due to their openness to reason and language, to their ability to be addressed, by words, by $\lambda$ óros. Language allows humans to transcend the biological parameters of their existence, so that the biological Umwelt is transformed into a literate human world, replete with language.

Basically speaking, the language of the genome (the bio-molecular messages spurring us to develop certain responses to environmental cues: $\mathrm{M} 1$ ) is negated, by the language of conscience and culture (M2), and this gives rise to various tensions and conflicts. In order to arrive at a viable situation, however, this negation of nature by culture must be negated or ('sublated') again (the negation of the negation, as Hegel phrases it: $\mathrm{M}_{3}$ ). By developing a profound understanding of our biological nature (starting with the human genome) as well as of the dynamics of human cultural existence (the spiritual dimension), both moments (nature and culture; nature and spirituality) may become reconciled again, on a higher level over complexity, so that desire may become sublimated into culture and negativity becomes sublated into responsibility (M3). 


\section{Genomics and Iconoclasm}

In the current era, as global mass media attention predominantly focusses on tensions between religion and science, between spirituality and secularisation, it seems relevant to highlight something which may easily be overlooked, namely a basic affinity between monotheism and the scientific world-view, captured by the term iconoclasm. In a religious context, iconoclasm refers to the tendency to discard idolatrous or iconic manifestations of religiosity (practices of producing and worshipping icons, statues, idols, etc.) in favour of scriptural, symbolic sources. Iconoclasm was inaugurated by Pharaoh Akhenaten (ca. 1353-1336 B.C.), and subsequently transferred as a quintessential feature to Judaism, Islam and Christianity (notably Protestantism).

Psychoanalyst of science Gaston Bachelard pointed out, however, that iconoclasm is also a distinctive feature of modern science $(1947,77 ; 1953,122)$, in the sense that science not only challenges narcissistic self-images, but also disrupts established (imaginary) world-views. Dialectically speaking, the objective of science is to understand nature or natural entities (M1), but instead of letting nature be (as happens in the case of artistic meditation or poetic exaltation), Bachelard explains how science actively transforms natural entities into something noumenal and abstract (bio-chemical molecules, captured in formula, symbols, equations, etc.) with the help of laboratory equipment. In dialectical terms, the concreteness and immediacy of natural entities becomes (Mi) negated or abolished (M2) by scientific knowledge production. Although research begins with self-constraint (letting things be, observing rather than consuming them), they are eventually transformed into something than can be technically manipulated. In other words, research entails negativity. The initial object (the natural phenomenon or Gestalt) becomes obliterated through measurements and quantification, so that a noumenal (physical, chemical, molecular) essence is revealed. Thus, the visible Gestalt (a tree, for instance) gives way to chemical letters and symbols $\left(\mathrm{CO}_{2}, \mathrm{H}_{2} \mathrm{O}, \mathrm{C}_{6} \mathrm{H}_{10} \mathrm{O}_{5}\right.$, etc.), and the living organism becomes "obliterated" (Zwart 2016). The living thing is broken down into basic components that can be represented with the help of letters: the symbolic alphabet of chemical compounds $\left(\mathrm{H}_{2} \mathrm{O}, \mathrm{CO}_{2}\right.$, etc.), genes (FOXP2, VMAT2, etc.), nucleic acids (A, C, G and T), amino acids (Ala, Arg, Asn, Asp, Leu, Lis, Met, etc.) and so on. Due to this symbolisation or literation of nature (or even obliteration) of nature, natural entities as living entities disappear from view, thus exemplifying the iconoclastic tendency of science. Only via iconoclastic

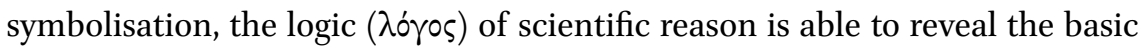
textuality ( $\lambda$ óros) of molecular systems. 
This example why the output of human genomics is not a recognisable portrait of a human being, but rather a stream of letters, something essentially textual: a formula, a sequence, a code. If a human genome sequence printed on canvas, it resembles a modernistic artwork, as we have seen. This iconoclastic tendency, at work in modern science, but also in modernistic art, reverberates with monotheistic precursors. From a historical perspective, however, iconoclasm is the exception rather than the rule. Cultures tend to speak to their adherents not only through words, but also via images. Ancient Greek culture, as we have seen, was primarily a visual culture and ancient sculptures of Greek and Roman culture, erected in public spaces, conveyed a moral message: become an athlete, transform yourself into a work of art, so that such statues actually functioned as exemplary idols. Such artworks entailed a form of moral propaganda (Lacan 1959-196o/1986). In contemporary commercials (displaying superbly healthy men and women for instance) such messages are still abundantly present (inciting us to become beautiful, healthy, fit, athletic, etc. by following a certain diets or fitness programs for instance). Monotheistic religions such as Judaism, Islam and Protestantism, however, are iconoclastic, relying on the Word (the Quran and the Bible) rather than on exemplary images. Monotheistic religions address their adepts via commandments and other normative, apodictic formula, while Catholicism can be seen as an intermediate form, a compromise between the imaginary and the symbolic. According to Hegel, Islam represents the most radical effort to abolish the imaginary and realise symbolic sublimity (Hegel 1970).

Modern science, however, is now reframing the normative dimension, by relying on high-tech forms of symbolisation, with the help of personality tests, IQ tests, BMI indicators, blood sample readings and so on. The idea that, in the near future, health science will increasingly address individuals in terms of personalised and digitalised data. Health gadgets will inform us whether our personal physiological performance (our body language, as recorded by smart wearable gadgets) concurs with societal expectations of normalcy: the molecularised version of the super-ego (Zwart 2016). As a result, human populations will increasingly be governed in an algorithmic manner, with the help of health data: algorithmic governance as the final stage of biopower (Rouvroy \& Stiegler 2016). Although human existence continues to be bi-textual, this bi-textuality is being radically reframed, namely as the tension between molecular messages coming from the body (transmitted by iPhones, smart watches and so on) and the standards of normalcy of the terabyte age, based on big scientific data collected by millions of citizens (Zwart 2016). Thus, the language of the Other (which gave rise to moral and spiritual experiences in the past) gives way to a secularised susceptibility to a different type of text: the super-ego of secular- 
ised culture urging us to become entrepreneurs of our health data and responsible managers of our personal health.

\section{Conclusion}

Human existence, we may conclude, is a dialectical interplay between two types of texts, biomolecular and socio-cultural ones. To deepen our understanding of this dialectics, a consistent dialogue between contemporary science (genomics and post-genomics) and the humanities (including religious studies) is indicated. This requires a shift of focus from ethical issues in the applied sense of the term towards the broader cultural ambiance of the science-society debate, for instance by reflecting on the impact of genomics on human self-understanding. If such a dialogue would focus solely on applied ethics deliberations, we may easily fall into the trap of seeing science as liberating and progressive, while metaphysical and religious world-views are framed as conservative and restrictive. A focus on applied ethics, moreover, may entail a plea for strategies of avoidance and compartmentalisation, delisting metaphysical, spiritual and religious issues from the agenda of the debate. I would rather advocate a strategy of retrieval: zooming out somewhat from frontstage bioethical quandaries towards the more fundamental backdrop issues. This allows us to discern how the bi-textuality of human existence is currently undergoing a transition, now that not only the physiological, but also the normative dimension is being reframed in biomolecular and terabyte terms.

\section{References}

Ahmed, Arzoo, and Mehrunisha Suleman. 2019. "Islamic Perspectives on the Genome and the Human Person: Why the Soul Matters". Included in this volume.

Aquinas, Thomas. 1922. Summa Theologica. Taurini: Marietti.

Aristoteles. 1986. De Anima / On the Soul (Loeb: Aristotle 8). Cambridge: Harvard University Press. London: Heinemann.

Bachelard, Gaston. 1947. La formation de l'esprit scientifique: Contribution à une psychanalyse de la connaissance objective. Paris: Vrin.

Bachelard, Gaston. 1953. Le matérialisme rationnel. Paris : Presses Universitaires de France.

Benslama, Fethi. 2009. Psychoanalysis and the challenge of Islam. Minneapolis: University of Minnesota Press.

Cheng, Andrew and Brian Cooper. 2001. "Introduction". The British Journal of Psychia- 
try. $178(40):$ s1-s2

Collins, Francis. 1999. "Medical and societal consequences of the Human Genome Project". New England Journal of Medicine. 341:28-37.

Collins, Francis. 2006. The language of God. A scientist presents evidence for belief. New York: Free Press (Simon \& Schuster).

Collins, Francis, 2011. The Language of Life: DNA and the revolution in personalised medicine. New York etc: Harper.

Davies, Kevin. 2001/2002. Cracking the genome: Inside the race to unlock human DNA. Baltimore and London:John Hopkins University Press.

Delbrück, Max. 1971. "Aristotle-totle-totle". In Of Microbes and Life, edited by Jacques Monod, Ernest Borek, 50-55. New York: Columbia University Press.

Dinan, Timothy, Roman Stilling, Catherine Stanton, John Cryan. 2015. "Collective unconscious: How gut microbes shape human behaviour". Journal of Psychiatric Research 63: 1-9.

Freud, Sigmund. 1917/1947. "Eine Schwierigkeit der Psychoanalyse“. Gesammelte Werke XII, 3-12. London: Imago.

Doudna, Jennifer and Samuel Sternberg. 2017. A crack in creation: gene editing and the unthinkable power to control evolution. Boston/New York: Houghton Mifflin Harcourt.

Freud, Sigmund. 1917/1947. "Eine Schwierigkeit der Psychoanalyse“. Gesammelte Werke XII. 3-12. London: Imago

Freud, Sigmund. 1920/1940. "Jenseits des Lustprinzips". Gesammelte Werke XIII, 1-70. Freud, Freud, Sigmund. 1930/1948. "Das Unbehagen in der Kultur." Gesammelte Werke XIV, 419-513. London: Imago.

Gilbert, Walter. 1992. A vision of the grail. In The Code of Codes. Scientific and Social Issues in the Human Genome Project, edited by Daniel Keyles and Leroy Hood, 83-97. Cambridge: Harvard University Press.

Hamer, Dean. 2005. The God Gene: How Faith Is Hardwired Into Our Genes. Anchor Books

Hegel, Georg, Friedrich Wilhelm. 197o. Vorlesungen über die Philosophie der Geschichte. Werke XII. Frankfurt am Main: Suhrkamp.

IHGSC. 2001. "Initial sequencing and analysis of the human genome". Nature 405: 86o-921.

IHGSC. 2004. "Finishing the euchromatic sequence of the human genome". Nature 431: 931-45.

Jinek Martin, Krzysztof Chylinski, Ines Fonfara, Michael Hauer, Jennifer Doudna, Emmanuelle Charpentier. 2012. "A Programmable Dual-RNA-Guided DNA Endonuclease in Adaptive Bacterial Immunity". Science 337(6o96): 816-821

Jung, Carl Gustav. 1911/2001. Symbole der Wandlung. Düsseldorf: Walter Verlag

Lacan, Jacques. 1953-1954/1975. Le séminaire I: Les Écrits Techniques de Freud. Paris: Édi- 
tions du Seuil.

Lacan, Jacques. 1955-1956/1981. Le Séminaire III: Les psychoses. Paris: Éditions du Seuil.

Lacan, Jacques. 1957-1958/1998. Le séminaire V: Les formations de l'inconscient. Paris: Éditions du Seuil.

Lacan, Jacques. 1961-1962. Le Séminaire IX: L'identification. Unpublished: http://www. valas.fr/.

Lacan, Jacques. 1966. "L'instance de la lettre dans l'inconscient ou la raison depuis Freud". In Écrits, 493-528. Paris: Éditions du Seuil.

Lacan, Jacques. 1974/2005. Le triomphe de la religion. Précédéde discours aux catholiques. Paris: Éditions du Seuil.

Lacan, Jacques. 1975-1976/2005. Le séminaire XXIII: Le sinthome. Paris: Éditions du Seuil Mauron, Alex. 2001. "Is the Genome the Secular Equivalent of the Soul?". Science 291 5505: 831-832. DOI: $10.1126 /$ science.1058768

Miller, Gary and Dean Jones. 2014. "The nature of nurture: refining the definition of the exposome." Toxicological Sciences 137 (1): 1-2. DOI:10.1093/toxsci/kft251

National Human Genome Research Institute. 2000. "June 2000 White House Event." Last modified August 29 2012. https://www.genome.gov/10oo1356/

Ommen, Gert-Jan van. 2005. "The human genome, revisited”. European Journal of Human Genetics 13: 265-70.

Rouvroy, Antoinette and Bernard Stiegler. 2016. "The digital regime of truth: from the algorithmic governmentality to a new rule of law". La Deleuziana: Online Journal of Philosophy 3: 6-29.

Rovelli, Carlo. 2013. "Aristotle's Physics" Aix-Marseille University. https://www.academia.edu/5739248/Aristotles_physics

Schrödinger, Erwin. 1944/1967. What is life? The physical aspect of the living cell / Mind and matter. London: Cambridge University Press.

Song, Robert. 2003. "The Human Genome Project as soteriological project". In Brave New World? Theology, Ethics and the Human Genome, edited by Celia Deane-Drummond, 164-184. London: Clark.

Stammers, Trevor. 2017. "Genome Editing - Creation, Kinds and Destiny: A Christian View. Paper presented at the conference". Islamic Ethics and the Genome Question, Research Centre for Islamic Legislation and Ethics. Doha, Qatar, April 4, 2017

Teilhard de Chardin, Pierre. 1955. The Phenomenon of Man. New York: Harper.

Teilhard de Chardin, Pierre. 1955. Le Phénomène humain. OEuvres 1. Paris: Editions du Seuil [translated as: The Phenomenon of Man (Bernard Wall). New York: Harper 1959; The Human Phenomenon (Sarah Appleton-Weber). Eastbourne: Sussex Academic Press, 2003.]

Venter, J. Craig. 2013. Life at the speed of light: From the double helix to the dawn of digital life. New York: Viking.

Watson, James. 2002. "A personal view of the project". In The Code of Codes. Scientific 
and Social Issues in the Human Genome Project, edited by Daneil J. Kevles and Leroy Hood, 164-173. Cambridge: Harvard University Press).

Zwart, Hub. 1993. Ethische consensus in een pluralistische samenleving: de gezondheidsethiek als casus. Amsterdam: Thesis Publishers.

Zwart, Hub and Cor Hoffer. 1998. Orgaandonatie en lichamelijke integriteit: een analyse van christelijke, liberale en islamitische interpretaties. Best: Damon. ISBN: 905573 0831

Zwart, Hub. 2007. "Genomics and self-knowledge. Implications for societal research and debate". New Genetics and Society, 26 (2): 181-202.

Zwart, Hub. 20o9. "Genomics and identity: the bioinformatisation of human life". Medicine, Health Care and Philosophy: a European Journal 12: 125-136.

Zwart, Hub. 2010. "The adoration of a map: Reflections on a genome metaphor". Genomics, Society \& Policy 5(3): 29-43.

Zwart, Hub. 2013. "The genome as the biological unconscious - and the unconscious as the psychic 'genome': a psychoanalytical rereading of molecular genetics". Cosmos and History: the Journal of Natural and Social Philosophy 9 (2): 198-222.

Zwart, Hub. 2015. "Human Genome Project: history and assessment". In International Encyclopaedia of Social \& Behavioural Sciences, (2) 311-317. Oxford: Elsevier.

Zwart, Hub. 2016. "The obliteration of life: depersonalisation and disembodiment in the terabyte age". New Genetics and Society 35 (1) 69-89. DOI: 10.1080/14636778.2016.1143770

Zwart, Hub. 2017. "From the Nadir of Negativity towards the Cusp of Reconciliation: A Dialectical (Hegelian-Teilhardian) Assessment of the Anthropocenic Challenge". Techné: Research in Philosophy and Technology 21:2-3. DOI: 10.5840/techne20176565 